\title{
Dynamics of Trade Specialization in Middle East and North Africa (MENA)
}

\author{
Duddy Roesmara Donna \\ Doctoral Program \\ Faculty of Economics and Business \\ Universitas Gadjah Mada \\ Indonesia \\ Tri Widodo \\ Center for Southeast Asian Social Studies (CESASS) \\ Faculty of Economics and Business \\ Universitas Gadjah Mada \\ Indonesia \\ Sri Adiningsih \\ Faculty of Economics and Business \\ Universitas Gadjah Mada \\ Indonesia
}

\begin{abstract}
This paper examines the dynamics of trade specialization and pattern of comparative advantage in the MENA region and countries for the period 2000 and 2010. An econometric model, Wald test, and the Spearman's rank correlation are applied. In the MENA region, analysis by industry classification and by country endowment classification indicates that the MENA region shows de-specialization rather than specialization in 2000-2010. Human Capital Intensive Industry and Resource Rich and Labor Importing Country have the most dynamic despecialization in the region. Human Capital Intensive Industry and Resource Rich and Labor Abundant Country have the most dynamic pattern of comparative advantage in the region. Qatar has the most dynamic despecialization in all industries, except in Primary Intensive Industry. Saudi Arabia has the most dynamic despecialization in Primary Intensive Industry. Qatar has also the most dynamic in the pattern of comparative advantage in all industries. By both, industry and country group classifications analysis, all countries in the MENA region have shown de-specialization with different speed, where Qatar has fastest de-specialization and Tunisia has slowest de-specialization.
\end{abstract}

Keywords: comparative advantage, dynamics of specialization, MENA, RSCA, econometric analysis, Wald test, Spearman's rank correlation.

JEL: F14, F17.

\section{Introduction}

International trade is one of the most important aspect in the economy of a country because it might increase growth and welfare. Many countries have used export to measure the performance of international trade. With globalization, liberalization, the performance of export in a country is expected to increase. Globalization, liberalization, economic integration, bilateral and multilateral agreement are the determinant of export structure for a country. Parallel with these, dynamics of comparative advantage and specialization become important issues (Widodo, 2009b; Wörz, 2005). Many regional trade agreements (RTAs) and regional economic integration have been achieved since the beginning of multilateral trade system (Widodo, 2009a and 200b). In Middle East and North Africa (MENA) region, the progress of RTAs is relatively dynamic and unnecessary overlapping (Dennis, 2006). Moreover, the underperformance of trade in MENA is about one third of their potency (Behar and Freund, 2011). The export of MENA countries is dominated by unsophisticated goods (Nasif, 2010). Export and import value dropped significantly in 2009 (Diop et al., 2010). Not only volume, the concentration of export has declined over time (Gourdon, 2010). Share to world export has declined from $8 \%$ in1981 until $2.5 \%$ in 2002. It was affected by the collapse of oil price in the 1980's (Dennis, 2006). 
Comparative advantage is one of the most important concepts for explaining the pattern of international trade (Widodo, 2010). This concept was firstly introduced by David Richardo, Heckscher and Ohlin with some relaxing assumptions. Both Richardo and Heckser-Ohlin have the same hypothesis that a country will specialize in products with have comparative advantage. In contrast, Intra-industry trade (Grubel and Lloyd) represents international trade within industries rather than between industries. Such trade is more beneficial than interindustry trade because it stimulates innovation and exploits economies of scale. In fact, the MENA region has low level of intra-industry trade (Behar and Freund, 2011).

This paper aims to analyze the dynamics of trade specialization in MENA region and countries with some classifications of industries, i.e. primary, natural resource intensive, unskilled labor intensive, technology intensive, and human capital intensive. The rest of this paper is organized as follows: sections 2 describe literature review, methodology is presented in section 3, section 4 represents result and discussion, and conclusion is presented in section 5 .

\section{Literature Review}

In line with globalization, liberalization and integration process in the world, an interesting issue involves country-specific specialization and the dynamic shifts in patterns of comparative advantage (Widodo, 2009b).

Table 1 Some Researches on Specialization and Convergence of Industrial Structure

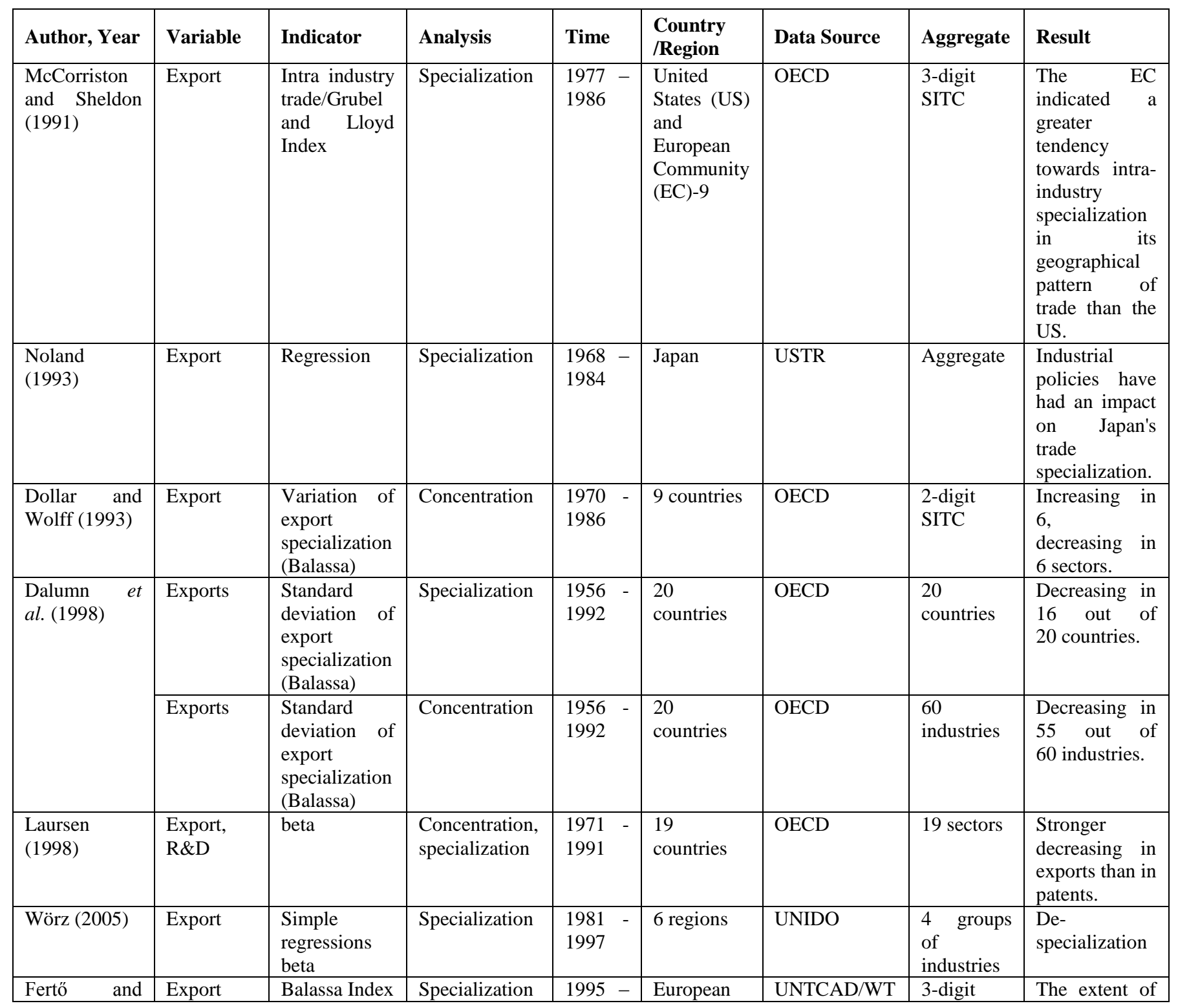




\begin{tabular}{|c|c|c|c|c|c|c|c|c|}
\hline Author, Year & Variable & Indicator & Analysis & Time & $\begin{array}{l}\text { Country } \\
\text { /Region }\end{array}$ & Data Source & Aggregate & Result \\
\hline Soós (2008) & & & & 2002 & Union - 15 & $\mathrm{O}$ & SITC & $\begin{array}{l}\text { trade } \\
\text { specialization } \\
\text { exhibits a } \\
\text { declining } \\
\text { trend. }\end{array}$ \\
\hline $\begin{array}{l}\text { Benedictis et } \\
\text { al (2009) }\end{array}$ & Export & $\begin{array}{l}\text { Generalized } \\
\text { Additive } \\
\text { Model } \\
\text { (GAM) with } \\
\text { country } \\
\text { specific fixed } \\
\text { effect }\end{array}$ & Specialization & $\begin{array}{l}1985- \\
2001\end{array}$ & $\begin{array}{l}39 \\
\text { countries }\end{array}$ & $\begin{array}{l}\text { Global } \\
\text { development } \\
\text { network } \\
\text { growth data }\end{array}$ & $\begin{array}{l}2 \text { and 4- } \\
\text { digit } \\
\text { SITC }\end{array}$ & $\begin{array}{l}\text { On average, } \\
\text { countries do } \\
\text { not } \\
\text { specialize; on } \\
\text { the contrary, } \\
\text { they divers. }\end{array}$ \\
\hline $\begin{array}{l}\text { Widodo } \\
\text { (2009a) }\end{array}$ & Export & $\begin{array}{l}\text { Mean, } \\
\text { standard of } \\
\text { deviation, } \\
\text { and skewness }\end{array}$ & Specialization & $\begin{array}{l}1976- \\
2005\end{array}$ & $\begin{array}{l}\text { Japan, } \\
\text { Korea, } \\
\text { China, and } \\
\text { ASEAN5 } \\
\text { countries }\end{array}$ & $\begin{array}{l}\text { UN- } \\
\text { COMTRADE }\end{array}$ & $\begin{array}{l}\text { 3-digit } \\
\text { SITC }\end{array}$ & $\begin{array}{l}\text { The increases } \\
\text { in } \\
\text { comparative } \\
\text { advantage } \\
\text { have been } \\
\text { mainly } \\
\text { encouraged by } \\
\text { de- } \\
\text { specialization. }\end{array}$ \\
\hline $\begin{array}{l}\text { Widodo } \\
\text { (2009b) }\end{array}$ & Export & $\begin{array}{l}\text { Simple } \\
\text { regressions } \\
\text { beta and } \\
\text { Spearman's } \\
\text { rank } \\
\text { correlation }\end{array}$ & Specialization & $\begin{array}{l}1985- \\
2005\end{array}$ & $\begin{array}{l}\text { Japan, } \\
\text { Korea, } \\
\text { China, and } \\
\text { ASEAN5 } \\
\text { countries }\end{array}$ & $\begin{array}{l}\text { UN- } \\
\text { COMTRADE }\end{array}$ & $\begin{array}{l}\text { 3-digit } \\
\text { SITC }\end{array}$ & $\begin{array}{l}\text { De- } \\
\text { specialization } \\
\text { together with } \\
\text { convergence } \\
\text { in the pattern } \\
\text { of trade } \\
\text { specialization. }\end{array}$ \\
\hline $\begin{array}{l}\text { Martincus and } \\
\text { Estevadeordal } \\
\text { (2009) }\end{array}$ & Production & $\begin{array}{l}\text { Panel data } \\
\text { regression }\end{array}$ & Concentration & $\begin{array}{l}1985- \\
1998\end{array}$ & $\begin{array}{l}10 \\
\text { members of } \\
\text { LAIA }\end{array}$ & UNIDO & $\begin{array}{l}\text { 3-digit } \\
\text { ISIC }\end{array}$ & $\begin{array}{l}\text { Reducing } \\
\text { own most } \\
\text { favored nation } \\
\text { tariffs is } \\
\text { associated } \\
\text { with } \\
\text { increasing } \\
\text { manufacturing } \\
\text { production } \\
\text { specialization. }\end{array}$ \\
\hline
\end{tabular}

Specialization is important to be studied because it can affect the speed of economic growth and welfare (Martincus and Estevadeordal, 2009). Moreover, specialization in the backward sector is consistent with output growth rate (Lane, 1996). Several studies present evidences on the evolution of specialization indicators over periods of declining trade barriers in developed countries (Martincus and Estevadeordal, 2009). Furthermore, economic integration can improve efficiency and competitiveness because of the development of a country's specialization (Widodo, 2009b). On the other hand, export diversification has a strong and positive impact on growth, through various channels (Rouis and Tabor, 2013). McCorriston and Sheldon (1991), Noland (1993), Dollar and Wolff (1993), Dalumn et al. (1998), Laursen (1998), Wörz (2005), Fertő and Soós (2008), Benedictis et al (2009), Widodo (2009a and 2009b), Martincus and Estevadeordal (2009), among others, examine this issue. Some of them find specialization as a conclusion and some of them get de-specialization. Table 1 provides a summary of these researches. Gourdon (2010) finds that export concentration in MENA has declined over time that reflects some decrease in the concentration among sectors. On the other hand, MENA region has low level of intra-industry trade (Behar and Freund, 2011). In other word, it means low diversification or high specialization. Rouis and Tabor (2013) find that export diversification in MENA countries has been limited. Some countries in the region are underperforming in discovering new exports than other countries with similar income levels. Moreover, all countries rely heavily on a few export commodities that are generally produced with low levels of skill and are unsophisticated. These results may be contradictive. 


\section{Methodology}

\subsection{Data}

This study uses the data on exports published by the United Nations (UN), namely the United Nations Commodity Trade Statistics Database (UN Comtrade) i.e. 3-digit Standard International Trade Classification (SITC) Revision 2; and focuses on 237 groups of products (as classified under SITC). There are still two groups of products (SITC), which are not included in this research due to the unavailability of data, i.e. SITC 675 (hoop and strip of iron or steel, hot-rolled or cold-rolled) and 911 (postal packages not classified according to kind). When discussing industries, the study concentrates on 235 groups of products (SITC - 3-digit level) classified by factor intensities, and uses the classification of industries by the Empirical Trade Analysis / ETA (Hinloopen and Marrewijk, n.d.). Based on the UN Conference on Trade and Development (UNCTAD)/World Trade Organization (WTO) classification (SITC Rev. 3), ETA distinguishes the following six products or industries: (1) primary industries (83 SITC); (2) natural resource- intensive industries (21 SITC); (3) unskilled labor- intensive industries (26 SITC); (4) technology-intensive industries (62 SITC); (5) human capital-intensive industries (43 SITC); and (6) others (5 SITC).

In World Bank research (World Bank, 2007; Gourdon, 2010; Shui and Walkenhorst, 2010; Gatti, et.al., 2013), the members of MENA region consists of Algeria, Bahrain, Djibouti, Egypt, Iran, Iraq, Jordan, Kuwait, Lebanon, Libya, Morocco, Oman, Qatar, Saudi Arabia, Syria, Tunisia, United Arab Emirates, West Bank and Gaza, and Yemen, but this research was focused in 14 countries of MENA countries. Because of unavailability of data, Djibouti, Iraq, Oman, West Bank and Gaza were not included in this research. Based on capital and labor abundance, the countries are divided in three groups (Shui and Walkenhorst, 2010), i.e. resource-rich and laborimporting (RRLI) countries (United Arab Emirates, Saudi Arabia, Qatar, Oman, Libya, Kuwait, and Bahrain), resource-rich and labor-abundant (RRLA) countries (Yemen, Syria, Iran, and Algeria), and resource-poor and labor-importing (RPLA) countries (Tunisia, Morocco, Lebanon, Jordan, and Egypt).

\subsection{Revealed Symmetric Comparative Advantage}

Revealed Symmetric Comparative Advantage (RSCA) Index (Laursen, 1998) is used to measure comparative advantage. The RSCA index was developed by the Revealed Comparative Advantage (RCA) or Balassa index (Balassa 1965). The RCA and RSCA indexes are formulated as follows:

$\mathrm{RCA}_{\mathrm{ij}}=\left(\mathrm{x}_{\mathrm{ij}} / \mathrm{x}_{\mathrm{in}}\right) /\left(\mathrm{x}_{\mathrm{rj}} / \mathrm{x}_{\mathrm{m}}\right) \ldots$

$\operatorname{RSCA}_{i j}=\left(\mathrm{RCA}_{\mathrm{ij}}-1\right) /\left(\mathrm{RCA}_{\mathrm{ij}}+1\right)$

where RCAij represents revealed comparative advantage of country $i$ for group of products (SITC) $j$; and $\mathrm{x}_{\mathrm{ij}}$ denotes total exports of country i in group of products (SITC) $j$. Subscript $r$ represents all countries except country $i$, and subscript $n$ stands for all groups of products (SITC) except group of product $j$. To avoid double counting, the country and group of products under consideration is excluded from the measurement so that the bilateral exchange is more exactly represented (Vollrath,1991; Wörz, 2005; Widodo, 2010).

The range of the RCA index values is from zero to infinity, $0 \leq \mathrm{RCA}_{\mathrm{ij}} \leq \infty$. $\mathrm{RCA}_{\mathrm{ij}}$ greater than one means that country has a comparative advantage in group of products $j$. On the other hand, $\mathrm{RCA}_{\mathrm{ij}}$ less than one implies that country $i$ has a comparative disadvantage in product $j$. Since the $\mathrm{RCA}_{\mathrm{ij}}$ turns out to have values that cannot be compared on both sides of one, the index is made to be a symmetric index (Laursen, 1998) and is called the Revealed Symmetric Comparative Advantage. The RSCA $\mathrm{ij}_{\mathrm{ij}}$ index ranges from one to one or $0 \leq \mathrm{RSCA}_{\mathrm{ij}} \leq 1$. $\mathrm{RSCA}_{\mathrm{ij}}$ greater than zero implies that country $i$ has a comparative advantage in product $j$. In contrast, $\mathrm{RSCA}_{\mathrm{ij}}$ less than zero implies that country $i$ has a comparative disadvantage in product $j$.

\subsection{The Dynamics of Specialization}

An econometric model (3) is commonly used to examine the dynamics of comparative advantage (Laursen, 1998; Wörz, 2005; and Widodo, 2009):

$R S C A_{i j, T}=\alpha+\beta R S C A_{i j, 0}+\varepsilon_{i j}$

where RSCA ij,T and RSCAij, 0 are the RSCA indexes of country $i$ in product $j$ for years $T$ and 0 , respectively. $\varepsilon_{i j}$ denotes white noise error term. The coefficient $\beta$ indicates whether the existing comparative advantage or specialization patterns have been reinforced or not during the years of observation. 
If $\beta$ is not significantly different from one $(\beta=1)$, there is no change in the overall degree of specialization. $\beta>1$ indicates increased specialization of the respective country. Finally, $0 \leq \beta \leq 1$ indicates de-specialization; that is, a country has gained a comparative advantage in industries where it did not specialize and has lost competitiveness in those industries where it was initially heavily specialized (Wörz 2005). In the event of $\beta \leq 0$, no reliable conclusion can be drawn on purely statistical grounds; the specialization pattern is either random, or it has been reversed. This equation is conducted for regional or country analysis.

Different Dynamics in the Specialization across Industries and Countries

It might be believed that the dynamics in specialization across countries and across industries are different. To examine this issue in the MENA industry classification (based on Empirical Trade Analysis/ETA classification), dummy variables are added for industries $\left(D_{i}^{P}\right)$ into equation (4):

$$
R S C A_{i j, T}=\alpha+\beta R S C A_{i j, 0}++\sum_{i=1}^{4} \gamma_{i}\left(D_{i}^{P} R S C A_{i j, 0}\right)+\omega_{i j}
$$

The econometric model (4) is applied for each country as denoted by $i$ :

- $\quad D_{1}^{P}(1=$ natural resource-intensive industries, $0=$ otherwise $)$,

- $\quad D_{2}^{P}(1=$ unskilled labor-intensive industries, $0=$ otherwise $)$,

- $\quad D_{3}^{P}(1=$ technology-intensive industries, $0=$ otherwise $)$,

- $\quad D_{4}^{P}(1=$ human capital-intensive industries, $0=$ otherwise $)$,

- $\quad$ the coefficient of $\alpha$ means primary industries.

To examine this issue in the MENA country groups (based on World Bank Classification above), dummy variables are added for countries $\left(D_{i}^{C}\right)$ into equation (5):

$$
R S C A_{i j, T}=\alpha+\beta R S C A_{i j, 0}++\sum_{i=1}^{2} \gamma_{i}\left(D_{i}^{C} R S C A_{i j, 0}\right)+\omega_{i j}
$$

The econometric model (5) is applied for each country as denoted by $i$ :

- $D_{1}^{C}(1=$ resource rich-labor abundance countries, $0=$ Otherwise $)$,

- $D_{2}^{C}(1=$ resource rich-labor importing countries, $0=$ Otherwise $)$,

- the coefficient of $\alpha$ means resource poor-labor abundance countries.

Since the data used in this paper are cross-sectional, it may be necessary to deal with the assumptions of the classical regression model. Conventional wisdom says that the problem of autocorrelation is a feature of time series data and heteroscedasticity is a feature of cross-sectional data (Gujarati 1995). Therefore, heteroscedasticity might be in our estimation. Wörz (2005) also finds that heteroscedasticity was initially a problem; therefore, the robust standard errors computed using the White/sandwich estimator of variance were employed. The existence of autocorrelation also might be possible. When the form of heteroscedasticity is unknown, it might not be possible to get efficient estimates of the parameter using weighted least squares (WLS). The ordinary least squares (OLS) gives consistent parameter estimates in the presence of heteroscedasticity but the usual OLS standard errors will be incorrect and should not be used for the inference purposes. Hence, this paper applies Heteroscedasticity and Autocorrelation Consistent Covariance (HAC) when the usual OLS has violated the homoscedasticity or noautocorrelation assumptions (Widodo, 2009b).

There are two possible approaches, i.e. Heteroscedasticity Consistent Covariance (White) and HAC Consistent Covariance (Newey-West).To determine which approach is suitable for a specific model, the following three stages are undertaken. First, the OLS is applied and then the residual tests on heteroscedasticity and autocorrelation are conducted. If the test shows that there are no autocorrelation and heteroscedasticity simultaneously, then the OLS is applied. Second, if only heteroscedasticity exists, the White Heteroscedasticity Consistent Covariance is used. Third, if the autocorrelation and heteroscedasticity exist, the HAC Consistent Covariance (Newey-West) is applied (Widodo, 2009b). 


\section{$\underline{\text { Several Tests }}$}

The dynamic specializations across country groups as well as across industries can be examined by looking at the significance of the corresponding dummy variables. Wald-test is conducted to test if there is any coefficient of specialization equal one and is coefficient of specialization same to another one. Not only to examine the pattern of comparative advantage, Spearman's rank correlation is also applied to examine the shift of comparative advantage for ten years. The degree of linear association between two series of RSCA can be compared by the Spearman's Rank Correlation Coefficient which is given as follows Widodo, 2009a and 2009b):

$$
\rho_{\mathrm{s}, \mathrm{Ct}_{\mathrm{a}}, \mathrm{Ct}_{\mathrm{b}}}=1-6\left[\frac{\sum_{\mathrm{i}=1}^{\mathrm{n}} \mathrm{d}_{\mathrm{R}_{\mathrm{it}}}^{2}}{\mathrm{n}\left(\mathrm{n}^{2}-1\right)}\right] \cdots
$$

Where:

$\rho_{\mathrm{s}, \mathrm{Ct}_{\mathrm{a}}, \mathrm{Ct}_{\mathrm{b}}}=$ the Spearman's Rank Correlation Coefficient between county C's RSCA at time $t_{\mathrm{a}}$ (symbol: $\mathrm{Ct}_{\mathrm{a}}$ ) and country C's RSCA at time $\mathrm{t}_{\mathrm{b}}\left(\right.$ symbol: $\left.\mathrm{Ct}_{\mathrm{b}}\right)$.

$\mathrm{d}_{\mathrm{R}_{\mathrm{j}}}^{2}=\left(\mathrm{R}_{\mathrm{RSCA}_{\mathrm{jc}, \mathrm{t}_{\mathrm{a}}}}-\mathrm{R}_{\mathrm{RSCA}_{\mathrm{jc}, \mathrm{t}_{\mathrm{b}}}}\right)^{2}$ for across time (years).

$\mathrm{R}_{\mathrm{RSCA}_{\mathrm{jc}, \mathrm{t}_{\mathrm{a}}}}=$ the rank of country C's RSCA of group of products $\mathrm{j}$ at time $t_{\mathrm{a}}$

$\mathrm{R}_{\mathrm{RSCA}_{\mathrm{jc}, \mathrm{t}_{\mathrm{b}}}}=$ the rank of country C's RSCA of group of products $\mathrm{j}$ at time $\mathrm{t}_{\mathrm{b}}$

$t_{a}$ and $t_{b}$ is time

The Spearman's rank correlation coefficients range from -1 (a perfect negative relationship) and +1 (a perfect positive relationship). A value of 0 indicates no linear relationship. Within a specific country, it is applied across times to analyze the dynamic shift in comparative advantage. If the correlation is closer to one (1), the shift in comparative advantage is less dynamic. In contrast, if it is closer to minus one (-1), the shift in comparative advantage is more dynamic.

\section{Result and Discussion}

$\underline{\text { Region Analysis }}$

Table 2 represents the estimation results of econometric model equation (3) for two years, 2000 and 2010 in case of MENA region. Column 2 shows the estimate of coefficients of specialization, and column 3 describes the Wald test (whether the coefficient equals one or not). It is clear that all coefficients of specialization are between 0 and 1 , and statically different from 1 (Wald-test) for either by industry or by country endowment classifications. It means that the MENA region exhibit de-specialization. Within industries, Human Capital Intensive Industry has the most dynamic de-specialization (0.64). Meanwhile, within country endowment classification, Resource Rich and Labor Importing Country has the most dynamic de-specialization (0.58). 
Table 2 The MENA Region's Coefficient of Specialization and Wald-test

\begin{tabular}{|c|c|c|}
\hline Classification & $\begin{array}{l}\text { Coefficient of } \\
\text { Specialization } \\
\end{array}$ & Wald-test \\
\hline Total of MENA & 0.71 & $511.57 * * *$ \\
\hline \multicolumn{3}{|l|}{ Industry Classification by ETA: } \\
\hline 1. Primary Product & 0.74 & $157.37 * * *$ \\
\hline 2. Natural Resource Intensive Product & 0.73 & $28.75 * * *$ \\
\hline 3. Unskilled Labor Intensive Product & 0.73 & $88.54 * * *$ \\
\hline 4. Technology Intensive Product & 0.69 & $126.68 * * *$ \\
\hline 5. Human Capital Intensive Product & 0.64 & $137.44 * * *$ \\
\hline \multicolumn{3}{|l|}{ Country Endowment Classification: } \\
\hline 1. Resource Poor and Labor Abundant Country & 0.71 & $197.95^{* * *}$ \\
\hline 2. Resource Rich and Labor Abundant Country & 0.73 & $78.40 * * *$ \\
\hline 3. Resource Rich and Labor Importing Country & 0.58 & $298.95 * * *$ \\
\hline
\end{tabular}

Tables 3 and 4 show the results of the Wald-test that is used for examining the coefficient of specialization across industries (shown by equation 4) and across country endowment group (shown by equation 5), respectively. Table 3 shows that for across industries, all coefficients of specialization vary statistically. Primary industry has statistically different coefficients of specialization with those of Natural Resource Intensive Industry and Unskilled Labor Intensive Industry, but it has statistically similar coefficients of specialization with those of Technology Intensive Industry and Human Capital Industry. Natural Resource Intensive Industry has statistically different those of the other industries. Table 4 shows that RPLA has statistically different coefficients of specialization with those of RRLA and RRLI. Meanwhile, RRLI has statistically the same coefficient of specialization with that of RRLA.

Table 3 Wald-test of Coefficient of Specialization: across Industries

\begin{tabular}{|l|l|l|l|l|l|}
\hline & Primary & $\begin{array}{l}\text { Nat Res } \\
\text { Intensive }\end{array}$ & $\begin{array}{l}\text { Uns Lab } \\
\text { Intensive }\end{array}$ & $\begin{array}{l}\text { Tech } \\
\text { Intensive }\end{array}$ & $\begin{array}{l}\text { Hum } \\
\text { Cap } \\
\text { Intensive }\end{array}$ \\
\hline Primary & & & & & \\
\hline Nat Res Int & $3.91 * *$ & & & & \\
\hline Uns Lab Int & $6.05 * *$ & $7.57 * * *$ & & & \\
\hline Tech Int & 1.02 & $4.17 * *$ & 1.79 & & \\
\hline Hum Cap Int & 1.41 & $4.26 * *$ & 1.04 & 0.07 & \\
\hline
\end{tabular}

Source: UN-COMTRADE, authors' calculation.

* Significant at $\alpha=10 \%,{ }^{* *}$ significant at $\alpha=5 \%$, ** significant at $\alpha=1 \%$ at $\alpha=5 \%, * * *$ significant at $\alpha=1 \%$

Table 4 Wald-test of coefficient of specialization across Country Groups

\begin{tabular}{|l|l|l|l|}
\hline & RPLA & RRLA & RRLI \\
\hline RPLA & & & \\
\hline RRLA & $6.24 * *$ & & \\
\hline RRLI & $5.52 * *$ & 0.01 & \\
\hline
\end{tabular}

Source: UN-COMTRADE, authors' calculation.

* Significant at $\alpha=10 \%$, ** significant at $\alpha=5 \%$, ** significant at $\alpha=1 \%$ at $\alpha=5 \%$, *** significant at $\alpha=1 \%$

Table 5 shows the calculation results of Spearman's rank correlation coefficient by industry classification and by country endowment classification across time 2010 and 2010. The values are positive and statitiscally significant different from one at level of significance $\alpha=1 \%$. Within industries, the pattern of comparative advemntage in Human Capital Intensive Industry exhibits the most dynamic shown by the smallest of Spearman's rank correlation coeffient (0.55). Meanwhile, within countries the pattern of comparative advemntage in Resource Rich and Labor Abundant Country has the most dynamic (0.50). 
Table 5 Spearman's Rank Correlation across Period, 2000-2010

\begin{tabular}{|l|l|}
\hline Classification & $\begin{array}{l}\text { Spearman Rank } \\
\text { Correlation }\end{array}$ \\
\hline Total of MENA & $0.68^{* * *}$ \\
\hline Industry Classification: & \\
\hline 1. Primary Product & $0.73^{* * *}$ \\
\hline 2. Natural Resource Intensive Product & $0.65^{* * *}$ \\
\hline 3. Unskilled Labor Intensive Product & $0.73^{* * *}$ \\
\hline 4. Technology Intensive Product & $0.65^{* * *}$ \\
\hline 5. Human Capital Intensive Product & $0.55^{* * *}$ \\
\hline Country Endowment Classification: & \\
\hline 1. Resource Poor and Labor Abundant Country & $0.71^{* * *}$ \\
\hline 2. Resource Rich and Labor Abundant Country & $0.50^{* * *}$ \\
\hline 3. Resource Rich and Labor Importing Country & $0.60^{* * *}$ \\
\hline
\end{tabular}

Source: UN-COMTRADE, authors' calculation.

* Significant at $\alpha=10 \%, * *$ significant at $\alpha=5 \%, * * *$ significant at $\alpha=1 \%$ at $\alpha=5 \%, * * *$ significant at $\alpha=1 \%$

Country Analysis

Table 6 represents the estimation results of econometric model equation (3) by industry classification for two years, 2000 and 2010 in case of individual MENA countries. It is clear that all coefficients for all industries classification and all countries are statically between 0 and 1 for either by industry or by country endowment classifications, except Natural Resource Intensive Industry in Yemen (-0.02), Unskilled Labor Intensive Industry in Algeria (-3.11) and Saudi Arabia (1.09), Technology Intensive Industry in Iran (1.1) and Syria (1.05), Human Capital Intensive Industry in Syria (2.08) and Bahrain (1.03). All individual MENA countries exhibit despecialization rather than specialization.

Table 6 The MENA Country's Coefficient of Specialization and Wald-test

\begin{tabular}{|c|c|c|c|c|c|c|c|c|c|c|c|c|c|}
\hline \multirow[t]{2}{*}{ No } & \multirow[t]{2}{*}{ Countries } & \multicolumn{2}{|c|}{ Primary } & \multicolumn{2}{|c|}{ Nat Res Int } & \multicolumn{2}{|c|}{ Uns Lab Int } & \multicolumn{2}{|c|}{ Tech Int } & \multicolumn{2}{|c|}{ Hum Cap Int } & \multicolumn{2}{|c|}{ Total } \\
\hline & & Coeff. & W-test & Coeff. & W-test & Coeff. & $\mathrm{W}$-test & Coeff. & W-test & Coeff. & W-test & Coeff. & W-test \\
\hline 1 & Egypt & 0.78 & $8.06 * * *$ & 0.76 & 1.67 & 0.80 & $3.87 * * *$ & 0.98 & 0.04 & 0.74 & $6.81 * *$ & 0.81 & $17.8 * * *$ \\
\hline 2 & Jordan & 0.76 & $13.98 * * *$ & 0.69 & $6.77 * *$ & 0.70 & 2.09 & 0.79 & $5.62 * *$ & 0.74 & $4.60 * *$ & 0.73 & $38.49 * * *$ \\
\hline 3 & Lebanon & 0.76 & $14.57 * * *$ & 0.63 & 4.80 ** & 0.36 & $41.37 * * *$ & 0.63 & $11.92 * * *$ & 0.80 & $5.17 * *$ & 0.70 & $51.56 * * *$ \\
\hline 4 & Morocco & 0.86 & $4.44 * *$ & 0.85 & 1.82 & 0.89 & 1.56 & 0.89 & 1.64 & 0.41 & $13.77 * * *$ & 0.83 & 20.36 *** \\
\hline 5 & Tunisia & 0.81 & $10.11 * * *$ & 0.89 & 1.88 & 0.77 & $11.66 * * *$ & 0.88 & 2.63 & 0.67 & $3.09 *$ & 0.83 & $21.26^{* * *}$ \\
\hline 6 & Algeria & 0.84 & $13.13 * * *$ & 0.70 & $8.81 * * *$ & -3.11 & 0.98 & 0.67 & $37.18 * * *$ & 0.11 & $264.1 * * *$ & 0.81 & $49.42 * * *$ \\
\hline 7 & Iran & 0.86 & $3.41 *$ & 0.90 & 0.16 & 0.86 & 0.96 & 1.10 & 0.24 & 0.68 & $5.74 * *$ & 0.88 & $4.89 * *$ \\
\hline 8 & Syria & 0.94 & 0.61 & 0.86 & 0.25 & 0.74 & $3.16^{*}$ & 1.05 & 0.01 & 2.08 & $23.15^{* * * *}$ & 0.94 & 1.4 \\
\hline 9 & Yemen & 0.75 & $5.82 * *$ & -0.02 & $4.91 * *$ & 0.89 & 0.03 & 0.31 & $7.04 * *$ & 0.92 & 0.12 & 0.84 & $6.20 * *$ \\
\hline 10 & Bahrain & 0.57 & $13.22 * * *$ & 0.94 & 0.11 & 0.40 & $29.56 * * *$ & 0.19 & $127.1 * * *$ & 1.03 & 0.02 & 0.45 & $97.83 * * *$ \\
\hline 11 & Oman & 0.78 & $12.27 * * *$ & 0.89 & 0.29 & 0.05 & $49.41 * * *$ & 0.55 & 2.13 & 0.01 & $73.80 * * *$ & 0.61 & $44.27 * * *$ \\
\hline 12 & Qatar & 0.54 & $31.49 * * *$ & 0.00 & $285 * * *$ & 0.00 & $860000 * * *$ & 0.19 & $195.3 * * *$ & 0.00 & $1963 * * *$ & 0.33 & $224.3^{* * *}$ \\
\hline 13 & $\begin{array}{l}\text { Saudi } \\
\text { Arabia }\end{array}$ & 0.49 & $17.09 * * *$ & 0.77 & $4.29 *$ & 1.09 & 1.13 & 0.90 & $4.34 * *$ & 0.84 & 2.06 & 0.74 & $25.90 * * *$ \\
\hline 14 & $\begin{array}{l}\text { United } \\
\text { Arab } \\
\text { Emirates }\end{array}$ & 0.58 & $52.89 * * *$ & 0.53 & $4.85^{* *}$ & 0.40 & $22.07 * * *$ & 0.30 & $22.80 * * *$ & 0.62 & $11.62 * * *$ & 0.52 & $103.1 * * *$ \\
\hline
\end{tabular}

Source: UN-COMTRADE, authors' calculation.

* Significant at $\alpha=10 \%, * *$ significant at $\alpha=5 \%, * * *$ significant at $\alpha=1 \%$ at $\alpha=5 \%, * * *$ significant at $\alpha=1 \%$ 
Table 7 Spearman's Rank Correlation across Period, 2000-2010

\begin{tabular}{|c|c|c|c|c|c|c|c|}
\hline No & Countries & Primary & Nat Res Int & Uns Lab Int & Tech. Int & Hum Cap Int & Total \\
\hline 1 & Egypt & $0.77 * * *$ & $0.67 * * *$ & $0.80 * * *$ & $0.69 * * *$ & $0.81 * * *$ & $0.76 * * *$ \\
\hline 3 & Lebanon & $0.80 * * *$ & $0.83 * * *$ & $0.62 * * *$ & $0.57 * * *$ & $0.79 * * *$ & $0.75 * * *$ \\
\hline 5 & Tunisia & $0.81 * * *$ & $0.86 * * *$ & $0.92 * * *$ & $0.83 * * *$ & $0.43 * * *$ & $0.81 * * *$ \\
\hline 6 & Algeria & $0.72 * * *$ & $0.69 * * *$ & 0.13 & $0.54 * * *$ & $0.44 * * *$ & $0.57 * * *$ \\
\hline 7 & Iran & $0.78 * *$ & $0.59 * *$ & $0.43 * *$ & $0.55 * * *$ & $0.72 * * *$ & $0.64 * * *$ \\
\hline 10 & Bahrain & $0.59 * * *$ & $0.57 * * *$ & $0.69 * * *$ & $0.48 * * *$ & $0.47 * * *$ & $0.58 * * *$ \\
\hline 13 & Oman & $0.78 * * *$ & $0.62 * * *$ & 0.20 & $0.51 * * *$ & 0.05 & $0.55 * * *$ \\
\hline 14 & Qatar & 0.10 & 0.35 & -0.23 & 0.02 & 0.03 & 0.05 \\
\hline 15 & Saudi Arabia & $0.47 * * *$ & $0.70 * * *$ & $0.71 * * *$ & $0.56 * * *$ & $0.71 * * *$ & $0.60 * * *$ \\
\hline 16 & United Arab Emirates & $0.75 * * *$ & 0.59 & 0.17 & $0.29 * *$ & $0.65 * * *$ & $0.61 * * *$ \\
\hline
\end{tabular}

Source: UN-COMTRADE, author's calculation.

$*$ significant at $\alpha=10 \%$, ** significant at $\alpha=5 \%$, *** significant at $\alpha=1 \%$

Table 7 shows the calculation results of Spearman's rank correlation coefficient across time 2010 and 2010 by industry classification for MENA individual countries. The all coefficient are positive and statitiscally significant different from one at level of significance $\alpha=1 \%$. Qatar has the most dynamic in pattern of comparative advantage for all industries, except Primary Intensive Industry.

De-specialization and dynamic pattern of comparative advantage studies have been conducted some researchers. Wörz (2005) concluded that OECD countries (6 regions and 4 groups of industries) tend to de-specialization. With simple regression and Spearman rank correlation, Widodo (2009b) concluded that Japan, Korea, China, and ASEAN5 countries tend to de-specialization with convergence pattern of trade specialization. With standard of deviation, and skewness, Widodo (2009a) had the similar conclusion. Dallum, et al, (1998) used standard deviation of export specialization to analyze specialization and concentration of OECD countries and concluded that the most of countries tend to decreasing of specialization and concentration. With the different method, Laursen (1998), Fertő and Soós (2008), Benedicts et al. (2009), Diop, et al. (2012), Rouis and Tabor (2013) had the similar conclusion. This result strengthens the above research, including Dalunm, et al (1998), Laursen (1998), Wörz (2005), Fertö and Soós (2008), Benedicts et al (2009), Widodo (2009a), and Widodo (2009b), Diop, et. al. (2012), Rouis and Tabor (2013) that countries or industries tend to de-specialization. On the other hand, McCorriston and Sheldon (1991) and Dollar and Wolf (1993), has different conclusion that industries tend to specialization. In the future, intra industry trade (IIT) theory can be used to clarify RSCA analysis for specialization analysis. RSCA index and IIT index can be used together with linear trend analysis to compare the dynamics of comparative advantage (specialization versus de-specialization) in a country or region.

\section{Conclusion}

The RSCA, econometric model, Wald test, and Spearman's rank correlation are used to analyze the comparative advantage in MENA region and countries. In the MENA region, analysis by industry classification and by country endowment classification indicates that the MENA region shows de-specialization rather than specialization in 2000-2010. Within industries, Human Capital Intensive Industry has the most dynamic de-specialization. In addition, within country endowment classification, Resource Rich and Labor Importing Country has the most dynamic de-specialization. About the dynamics in pattern of comparative advantage, within industries the pattern of comparative advemntage in Human Capital Intensive Industry exhibits the most dynamic. Meanwhile, within countries the pattern of comparative advemntage in Resource Rich and Labor Abundant Country has the most dynamic. Qatar has the most dynamic de-specialization in all industries, except in Primary Intensive Industry. Saudi Arabia has the most dynamic de-specialization in Primary Intensive Industry. . Qatar has also the most dynamic in the pattern of comparative advantage in all industries. 


\section{References}

Behar, A., and Freund, C. (2011). The Trade Performance of the Middle East and North Africa. Middle East and North Africa Working Paper Series(53).

Benedictis, L., Gallegati, M., and Tamberi, M. (2009). Overall Trade Specialization and Economic Development: Countries Diversify. Review of World Economics, 145(1): 37-55

Dalumn, B., Laursen, K., and Villumsen, G. (1998). Structural Change in OECD Export Specialization Patterns: De Specialization and "Stickiness". International Review of Applied Economics, 12: 423 - 443

Dennis, A. (2006). The Impact of Regional Trade Agreements and Trade Facilitation. World Bank Policy Research Working Paper, 3837, 1-24.

Diop, N., Walkenhorst, P., and Lopez-Calix, J. R. (2010). Trade Reforms for Export Competitiveness: What Are the Issues for the Middle East and North Africa?. In N. Diop, P. Walkenhorst, and J. R. Lopez-Calix, Trade Competitiveness of Middle East and North Africa Policies for Export Diversification (page. 1-9). Washington DC: The World Bank.

Dollar, D. and Wolff, E.N. (1993). Competitiveness, Convergence, and International Specialization. Massachusetts: The MIT Press

Fertö, I. and Soós, K.A. (2008). Trade Specialization in the European Union and in Post-communist European Countries. Eastern European Economics,46(3): 5-28

Gatti, R., Morgandi, M., Broadmann, S., Urdinola, D. A., Moreno, J. M., Marotta, D., et al. (2013). Jobs for Shared Prosperity: Time for Action in the Middle East and North Africa. Washington DC: Word Bank Publications.

Gourdon, J. (2010). FDI Flows and Export Diversification: Looking at Extensive and Intensive Margin. In Diop, P. Walkenhorst, and J. R. Lopez-Calix, Trade Competitiveness of Middle East and North Africa Policies for Export Diversification (page. 13-46). Washington DC: The World Bank.

Hinloopen, J., dan Marrewijk, C. v. (n.d.). Factor Intensity Classification. Quoted 3 18, 2015, dari Empirical Trade Analysis Center: http://www2.econ.uu.nl/users/marrewijk/eta/intensity.htm

Laursen, K. (1998). Revealed Comparative Advantage and the Alternatives of Measures of International Specialization. DRUID Working Paper No. 98-30.

Lane, P.R. (1996). Trade Specialization, Endogenous Innovation and Growth. Journal of Economic Integration, 11(4): 492-509

Martincus, C.V. and Estevadeordal, A. (2009). Trade Policy and Specialization in Developing Countries. Review of World Economics, 145(2): 251-275

McCorriston, S. and Sheldon, I.M. (1991). Intra-Industry Trade and Specialization in Processed Agricultural Products: The Case of the US and the EC. Review of Agricultural Economics,13(2): 173-184

Noland, M. (1993). The Impact of Industrial Policy on Japan's Trade Specialization. The Review of Economics and Statistics, 75(2): 241-248

Rouis, M., and Tabor, S. R. (2013). Regional Economic Integration in the Middle East and North Africa Beyond Trade Reform. Washington DC: The World Bank.

Shui, L., and Walkenhorst, P. (2010). Regional Integration: Status, Developments, and Challenges. In N. Diop, P. Walkenhorst, and J. R. Lopez-Calix, Trade Competitiveness of Middle East and North Africa Policies for Export Diversification (hal. 267-297). Washington DC: The World Bank.

United Nations-Comtrade. (various years). Export and Import. Quoted in 3 11, 2015, from UN Comtrade: http://comtrade.un.org/db/

Vollrath, T. L. (1991). A theoretical evaluation of alternative trade intensity measures of revealed comparative advantage. Weltwirtschaftliches Archiv, 127(2), 265-280.

Widodo, T. (2009a). "Dynamcic Comparative Advantages in the ASEAN+3". Journal of Economic Integration, 24(3), 505-529.

Widodo, T. (2009b). Dynamics and Convergence of Trade Specialization in East Asia. Asia Pacific Journal of Economics and Business, 13(1), 31-56.

Widodo, T. (2010). Book Manuscript: International Trade, Regionalism and Dynamic Market. Yogyakarta: BPFE

World Bank. (2007). Middle East and North Africa Region: 2007 Economic Developments and Prospects. Washington DC: World Bank.

Wörz, J. (2005). Dynamic of Trade Specialization in Developed and Less Developed Countries. Emerging Market Finance and Trade, 41(3), 92-111. 